\title{
Quantifying electrochemical promotion of induced bipolar Pt particles supported on YSZ
}

\author{
Chun Xia a,b,c, Michael Hugentobler ${ }^{\mathrm{a}}$, Yongdan-Li ${ }^{\mathrm{c}}$, Christos Comninellis ${ }^{\mathrm{b}}$, Wolfgang Harbich ${ }^{\mathrm{a}, *}$ \\ a Institute of Condensed Matter Physics, Ecole Polytechnique Fédérale de Lausanne, CH-1015, Lausanne, Switzerland \\ b Institute of Chemical Sciences and Engineering, Ecole Polytechnique Fédérale de Lausanne, CH-1015, Lausanne, Switzerland

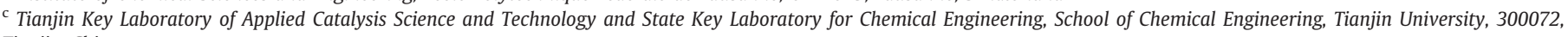 \\ Tianjin, China
}

\section{A R T I C L E I N F O}

\section{Article history:}

Received 30 July 2010

Received in revised form 23 August 2010

Accepted 24 August 2010

Available online 21 September 2010

\section{Keywords:}

Bipolar polarization

Non-percolated Pt particles

Isotopically labeled ${ }^{18} \mathrm{O}_{2}$

NEMCA

CO oxidation

\begin{abstract}
A B S T R A C T
Electrochemical promotion (EP) of CO oxidation is shown for the first time on induced bipolar Pt particles supported on yttria-stabilized zirconia (YSZ). These Pt particles are formed by sputter deposition of highpurity Pt metal followed by sintering. Conditions were chosen to stay below the percolation threshold of Pt particles. In-plane polarization of Pt particles results in a bipolar system and leads to the formation of a large number of galvanic cells partially or completely polarized. We have defined an equivalent number of active cells $\left(n_{\text {cell }}\right)$ which has been estimated from the oxygen evolution reaction as a function of the applied current on the two feed electrodes. The $\mathrm{CO}$ oxidation rate is measured under high vacuum conditions as a function of applied current. The use of isotopically labeled oxygen allows the discrimination of the faradaic process $\left({ }^{16} \mathrm{O}\right.$ from YSZ) from the non-faradaic process $\left({ }^{18} \mathrm{O}\right.$ from $\left.{ }^{18} \mathrm{O}_{2}\right)$ and to determine the faradaic efficiency $(\Lambda)$ and the rate enhancement $(\rho)$ parameters in this bipolar system. These results mark an important step in the realization of electrochemical promotion on highly dispersed catalysts.
\end{abstract}

(c) 2010 Elsevier B.V. All rights reserved.

\section{Introduction}

The catalytic activity of metal and metal oxide catalysts, deposited on solid electrolytes, can be increased in a pronounced manner by current or potential application between the catalyst and a gold electrode in an electrochemical cell of the type

Gaseous reactants, catalyst | solid electrolyte | Au electrode, gaseous reactants

This phenomenon in electrocatalysis is reported in the literature as electrochemical promotion (EP) or as non-faradaic electrochemical modification of catalytic activity (NEMCA). It has been studied during the last few years for numerous reactions using different catalysts and solid electrolytes [1-3].

Most electrochemical promotion studies have been carried out using solid electrolyte pellets on which a thin layer of catalysts was deposited on one side (working electrode) and a layer of gold on the other side (counterelectrode). A small gold electrode was used as a pseudoreference electrode [1-3]. This configuration which we will call conventional system in the following has generally low catalyst

\footnotetext{
* Corresponding author.

E-mail address: wolfgang.harbich@epfl.ch (W. Harbich).
}

dispersion and should be adapted, in terms of compactness, surface area, and applicability, for industrial systems.

It has been demonstrated recently that EP can be induced using the "bipolar" configuration [4-6]. In this configuration, application of an electrical field between two feeder electrodes induces charge separation on the catalyst particles resulting in two individual galvanic cells. This "bipolar" configuration opens new opportunities for practical applications of this phenomenon [7-9].

A major problem in the bipolar configuration is the determination of the classical EP parameters during operation (the rate enhancement ratio $\rho$ and the faradaic efficiency $\Lambda$ ). This is related to the difficulties involved in the determination of the effective number of operating galvanic cells $\left(n_{\text {cell }}\right)$ during bipolar polarization.

In this paper, we present for the first time a new technique for the experimental determination of $\Lambda$ in a bipolar configuration of a nonpercolated Pt catalyst dispersed on YSZ solid electrolyte. In this technique, a galvanostatic step is imposed to the system in the presence of $\mathrm{C}^{16} \mathrm{O}(\mathrm{g})$ and isotope ${ }^{18} \mathrm{O}_{2}(\mathrm{~g})$ under high vacuum conditions. This leads to the formation of $\mathrm{C}^{16} \mathrm{O}_{2}$ due to a faradaic reaction ( ${ }^{16} \mathrm{O}$ from YSZ) and $\mathrm{C}^{16} \mathrm{O}^{18} \mathrm{O}$ due to non-faradaic reaction $\left({ }^{18} \mathrm{O}\right.$ from $\left.{ }^{18} \mathrm{O}_{2}\right)$. From the amount of $\mathrm{C}^{16} \mathrm{O}_{2}$ and $\mathrm{C}^{18} \mathrm{O}_{2}$ formed, $\Lambda$ and $\rho$ can be determined. Isotopic ${ }^{18} \mathrm{O}_{2}$ as the oxidant has been used for the investigation of the mechanism of EP [10]. However, this is the first 
time in which ${ }^{18} \mathrm{O}_{2}$ is used for the quantification the EP of bipolar Pt particles supported on YSZ.

\section{Experimental}

The experimental setup used in this experiment has been described elsewhere [11] and only details specific to this investigation are given here.

A thin $(1 \mathrm{~mm})$ rectangular $(5 \times 10 \mathrm{~mm})$ YSZ pellet $\left(8 \% \mathrm{~mol} \mathrm{Y}_{2} \mathrm{O}_{3}-\right.$ stabilized $\mathrm{ZrO}_{2}$, Technox 802, Dynamic Ceramic) was used as a substrate to support the Pt catalyst. Two gold electrodes $(10 \mathrm{~mm} \times 1.5 \mathrm{~mm})$ with a thickness of approximately $0.5 \mathrm{~mm}$ were deposited on one side of the YSZ by application of metallorganic paste (Gwent Electronic Materials, Ltd., C70219R4) followed by calcination in air at $550{ }^{\circ} \mathrm{C}$. Platinum nanoparticles were generated by sputter deposition on the whole YSZ pellet using a differentially pumped CORDIS [12] ion source operated with $\mathrm{Ar}$ at $20 \mathrm{kV}$. The $\mathrm{Ar}$ partial pressure is lower than $10^{-4} \mathrm{~Pa}$, allowing energetic Pt atoms to hit the surface forming stable nucleation centers. The percolation threshold is determined by monitoring the electrical resistance between the two Au electrodes during deposition. Starting at few $G \Omega$, the deposition was interrupted when the resistance between the $\mathrm{Au}$ electrodes dropped to $0.5 \mathrm{M} \Omega$. The electrochemical cell is then sintered at $700{ }^{\circ} \mathrm{C}$ in air for 4 hours to obtain a non-percolated Pt catalyst as proved by the bare YSZ resistance between the gold electrodes after this procedure and by the SEM image (Fig. 1).

The morphology of dispersed Pt particles was characterized by scanning electron microscopy (SEM, XL30, Philips) (Fig. 1). The SEM topography reveals Pt particles well-dispersed $\left(1.7 \times 10^{9}\right.$ particles $\left.\mathrm{cm}^{-2}\right)$ on the YSZ surface with an average diameter of $60 \mathrm{~nm}$. Due to the morphology of the YSZ crystal, we very often observe particle islands separated by regions which are essentially free of Pt. The length of the three-phase boundary (TPB) amounts to $313 \mathrm{~m} \mathrm{~cm}^{-2}$.

The bipolar configuration is presented in Fig. 2. The potential difference is applied to the two gold electrodes and the Pt particles are not in ohmic contact, as can readily be seen in Fig. 1.

All measurements were carried out under high vacuum (HV) conditions with a background pressure of $10^{-6} \mathrm{~Pa}$ at $300^{\circ} \mathrm{C}$ by solid electrochemical mass spectroscopy (SEMS) as described in [13]. This

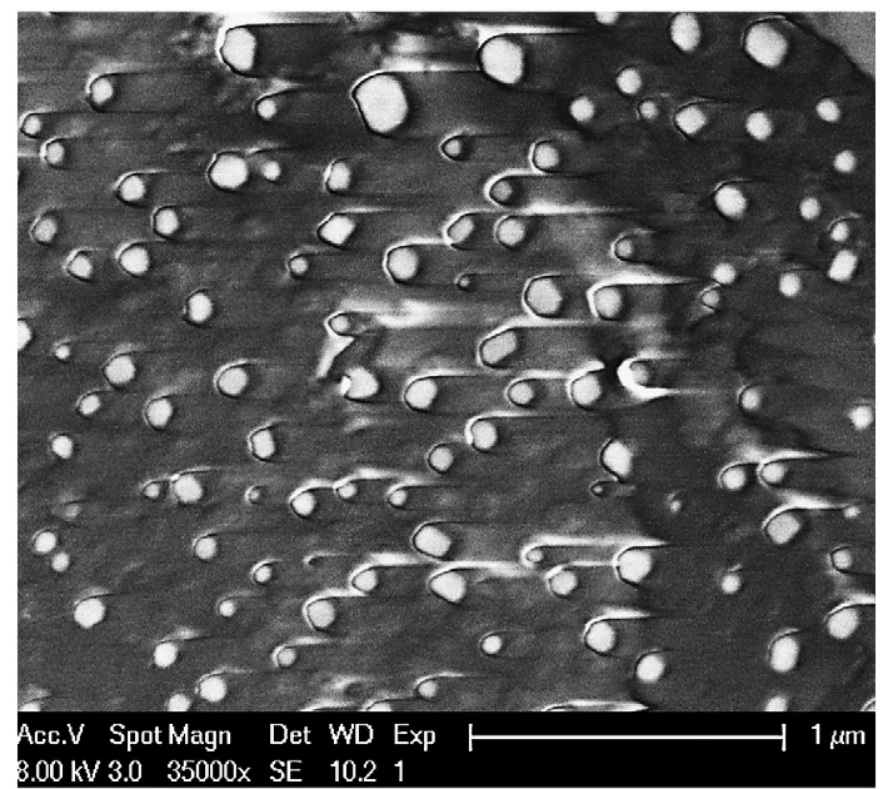

Fig. 1. SEM image of dispersed Pt particles by sputter deposition followed by calcination at $700{ }^{\circ} \mathrm{C}$ on YSZ. new electrochemical technique involves the imposition of a galvanostatic perturbation using a galvanostat-potentiostat (Model 362, EG\&G Princeton) to the system while monitoring the formation of electrochemical products released into the gas phase in situ by mass spectrometry (QMS, Pfeiffer, Prisma200). Electrochemical oxygen evolution (in the absence of gas), classical catalysis and electrochemical promotion (in the presence of reactive reactants, isotopically labeled ${ }^{18} \mathrm{O}_{2}\left(\mathrm{p}=10^{-5} \mathrm{~Pa}\right)$ and $\left.\mathrm{CO}\left(\mathrm{p}=10^{-6} \mathrm{~Pa}\right)\right)$ measurements were carried out using the same procedure.

\section{Results and discussion}

\section{1) Polarization in the absence of reactive gas}

During the galvanostatic step application to the conventional configuration and in the absence of any reactive gas, the main steady state anodic and cathodic reactions are oxygen evolution (Eq. (1)) and reduction of YSZ (Eq. (2)), respectively [13].

$$
{ }^{16} \mathrm{O}^{2-}=1 / 2{ }^{16} \mathrm{O}_{2}+2 \mathrm{e}^{-}
$$

$\mathrm{Zr}^{16} \mathrm{O}_{2}+2 \delta \mathrm{e}^{-}=\mathrm{Zr}^{16} \mathrm{O}_{2-\delta}+\delta^{16} \mathrm{O}$

The amount of oxygen released $\left(\mathrm{J}, \mathrm{mol} \mathrm{O}_{2} \mathrm{~s}^{-1}\right)$ in the absence of Pt particles can be calculated for a given current $I$ using Eq. (3):

$J=I / 4 F$

The situation is different in the effective bipolar configuration (Fig. 2). In fact, the application of an electrical field by the two feeder electrodes to the dispersed non-percolated platinum nanoparticles forms a certain number of partially or completely polarized galvanic cells, one side acting as an anode (Eq. (1)) and the other as a cathode (Eq. (2)). We define an equivalent number of completely polarized galvanic cells, $n_{\text {cell }}$, which can be obtained by Eq. (4):

$n_{\text {cell }}=J^{*} / J$

where $J^{*}$ is the amount of oxygen released in bipolar configuration $\left[\mathrm{mol} \mathrm{O}_{2} \mathrm{~s}^{-1}\right]$.

Fig. 3(a) shows the number of induced equivalent galvanic cells, $n_{\text {cell }}$, as a function of the applied current and Fig. 3 (b) the variation of cell potential with the applied current $n_{\text {cell }}$ is very small compared to the number of particles. In fact, it seems that only a small fraction of particles are polarized by the applied field. The increase of the number of induced equivalent galvanic cells with the applied current is related to the non-uniform Pt particle size distribution as shown in Fig. 1. In fact, it is expected that at low currents, only large particles are polarized, however, increasing current results in the polarization of smaller particles.

\section{2) Polarization in the presence of a reactive gas}

The galvanostatic step is applied to the bipolar configuration in the presence of reactive gas at $300{ }^{\circ} \mathrm{C}$. During polarization, both $\mathrm{C}^{16} \mathrm{O}_{2}$ and $\mathrm{C}^{16} \mathrm{O}^{18} \mathrm{O}$ are formed and monitored by mass spectrometry. The formation of $\mathrm{C}^{16} \mathrm{O}_{2}$ is due to a faradaic reaction $\left({ }^{16} \mathrm{O}\right.$ from YSZ) and $\mathrm{C}^{16} \mathrm{O}^{18} \mathrm{O}$ due to the non-faradaic reaction $\left({ }^{18} \mathrm{O}\right.$ from ${ }^{18} \mathrm{O}_{2}$, gas phase) as shown in Eqs. (6) and (7).

$\mathrm{C}^{16} \mathrm{O}+{ }^{16} \mathrm{O}^{2-}(\mathrm{YSZ})=\mathrm{C}^{16} \mathrm{O}_{2}+2 \mathrm{e}^{-}$

$\mathrm{C}^{16} \mathrm{O}+1 / 2^{18} \mathrm{O}_{2}(\mathrm{~g})=\mathrm{C}^{16} \mathrm{O}^{18} \mathrm{O}$ 


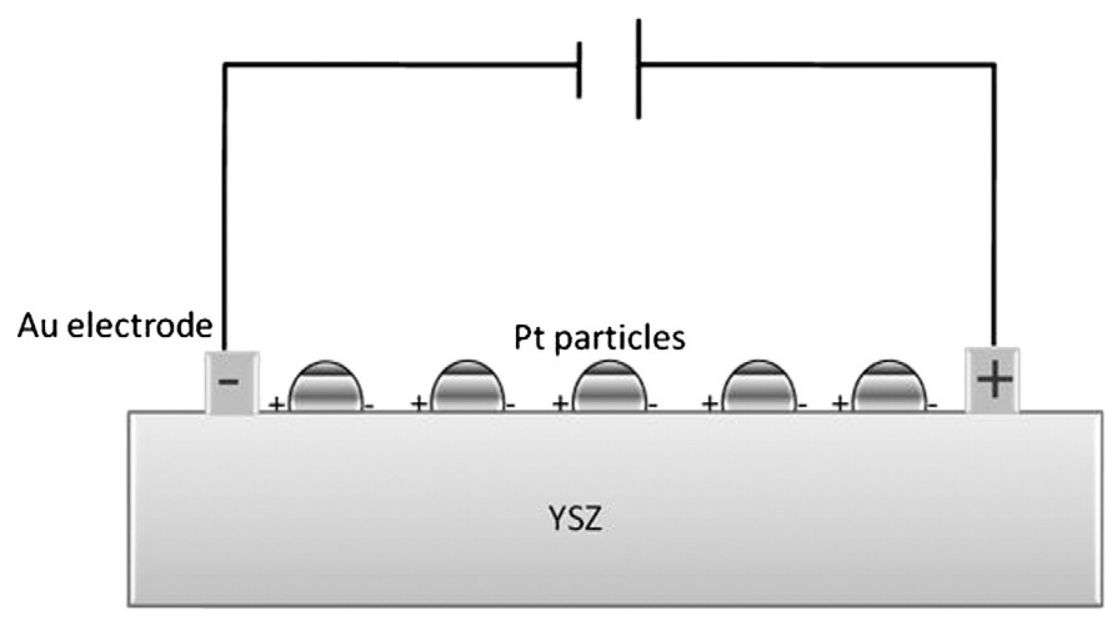

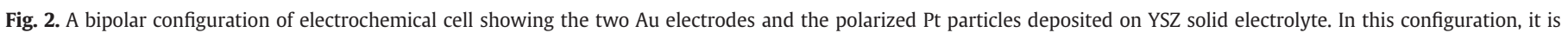
supposed that all particles are completely polarized.

The enhancement ratio $(\rho)$ and the faradaic efficiency $(\Lambda)$ due to the potential field application to the Pt particles (bipolar polarization) are given by Eqs. (8) and (9), respectively

$\rho=\frac{r_{\mathrm{C}^{16} \mathrm{O}_{2}}+\mathrm{r}_{\mathrm{C}^{16} \mathrm{O}^{18} \mathrm{O}}}{\mathrm{r}_{\mathrm{C}^{16} \mathrm{O}^{18} \mathrm{O}}^{\mathrm{O}}}$

$\Lambda=\frac{\mathrm{r}_{\mathrm{C}^{16} \mathrm{O}_{2}}+\Delta \mathrm{r}_{\mathrm{C}^{16} \mathrm{O}^{18} \mathrm{O}}}{\mathrm{r}_{\mathrm{C}^{16} \mathrm{O}_{2}}}=1+\frac{\Delta \mathrm{r}_{\mathrm{C}^{16} \mathrm{O}^{18} \mathrm{O}}}{\mathrm{r}_{\mathrm{C}^{16} \mathrm{O}_{2}}}$

where

$\mathrm{r}_{\mathrm{C}^{16} \mathrm{O}^{18} \mathrm{O}}^{\mathrm{O}}$ is the initial open-circuit catalytic rate.

$\mathrm{r}_{\mathrm{C}^{16} \mathrm{O}_{2}}$ is the rate of electrochemical formation of $\mathrm{C}^{16} \mathrm{O}_{2}$

$\mathrm{r}_{\mathrm{C}^{16} \mathrm{O}^{18} \mathrm{O}}$ is the catalytic rate of $\mathrm{C}^{16} \mathrm{O}^{18} \mathrm{O}$ under polarization.

$\triangle \mathrm{r}_{\mathrm{C}^{16} \mathrm{O}^{18 \mathrm{O}} \mathrm{O}}$ is the enhancement of the catalytic rate of $\mathrm{C}^{16} \mathrm{O}^{18} \mathrm{O}$ during polarization

Therefore, if $\Delta \mathrm{r}_{\mathrm{C}_{160} 18 \mathrm{O}}>0$, i.e. $\Lambda>1$, means the existence of electrochemical promotion. Fig. 4 shows the influence of the applied current and $n_{\text {cell }}$ on the catalytic rate of $\mathrm{C}^{16} \mathrm{O}^{18} \mathrm{O}$, electrochemically formed $\mathrm{C}^{16} \mathrm{O}_{2}$, as well as $\rho$ and $\Lambda$ in the bipolar configuration. With increasing applied current, the rate of $\mathrm{CO}_{2}$ formation $\left(\mathrm{C}^{16} \mathrm{O}_{2}\right.$ and $\left.\mathrm{C}^{16} \mathrm{O}^{18} \mathrm{O}\right)$ and $\rho$

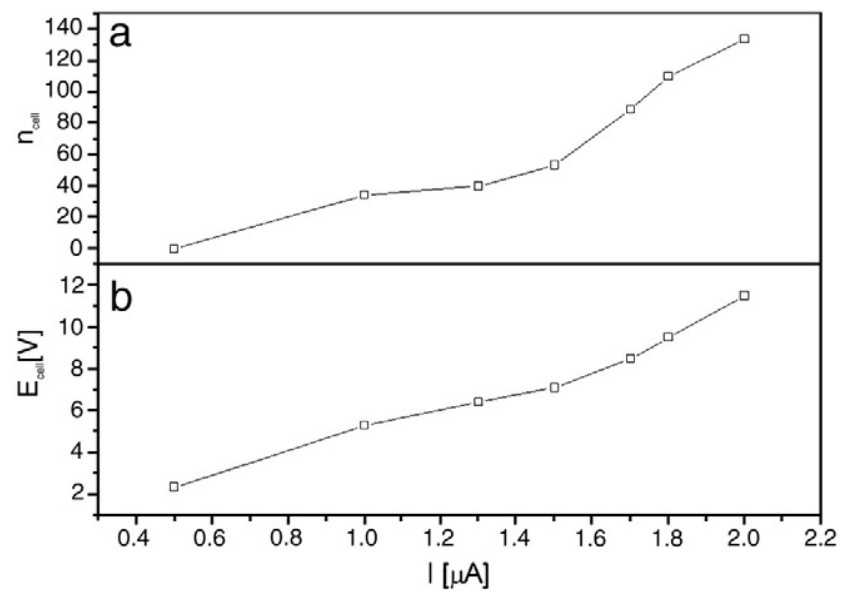

Fig. 3. (a) Influence of applied current on the number of equivalent galvanic cells $n_{\text {cell }}$. (b) Variation of cell potential in the bipolar configuration as a function of applied current. increases. This is due to the increasing number of cells $n_{\text {cell }}$ (Fig. $4 \mathrm{a}$ and b). However, the $\Lambda$ value which measures the faradaic efficiency of promotion is independent of the applied current and $n_{\text {cell }}$ indicating that all polarized particles behave similarly towards EP. Its absolute value of 1.8 proves the electrochemical promotion of catalysis on the polarized particles.

Notice that, in principle, we can calculate the $\Lambda$ value by the classical equation reported by Vayenas [2], but modified considering the equivalent number of galvanic cells $n_{\text {cell }}$ as

$\Lambda=2 \mathrm{~F} \frac{\left(\mathrm{r}_{\mathrm{C}^{16} \mathrm{O}_{2}}+\Delta \mathrm{r}_{\mathrm{C}^{16} \mathrm{O}^{18} \mathrm{O}}\right)}{\mathrm{In}_{\text {cell }}}$

This amounts to $\Lambda=0.086$ meaning no electrochemical promotion. However, our measurements show the formation of $\mathrm{O}_{2}$ in addition to $\mathrm{CO}_{2}$. This is due to the non-uniform current distribution leading to high local current densities.

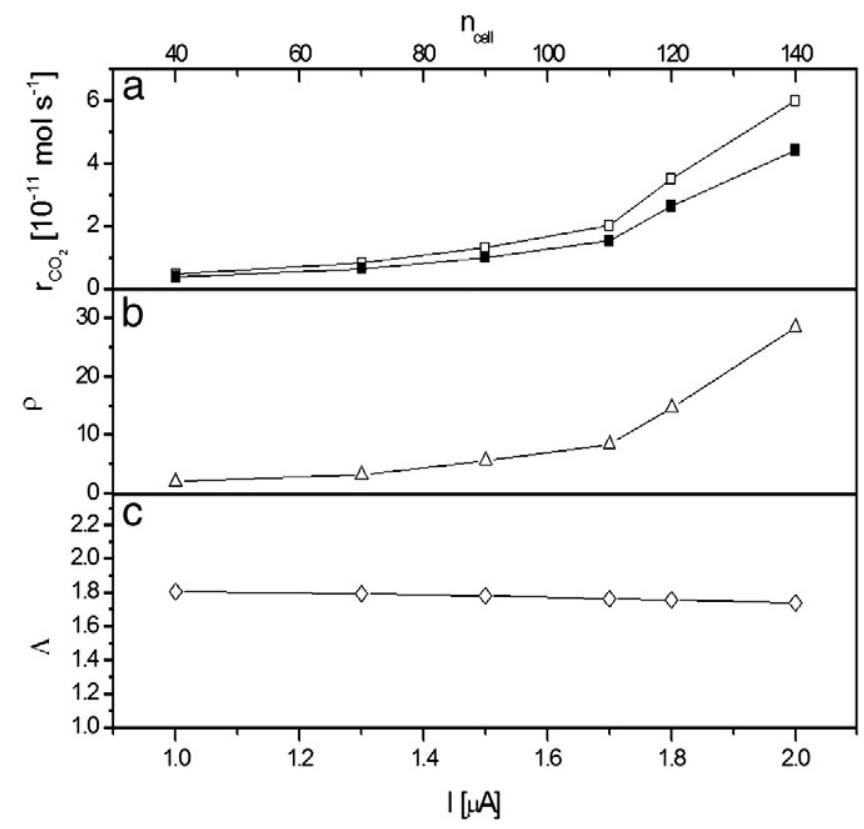

Fig. 4. The influence of applied current and $n_{\text {cell }}$ on $\mathrm{C}^{16} \mathrm{O}_{2}, \mathrm{C}^{16} \mathrm{O}^{18} \mathrm{O}$, rate enhancement ratio $(\rho)$ and faradaic efficiency $(\Lambda)$. 


\section{Conclusions}

A bipolar non-percolated Pt/YSZ catalyst is investigated at $300{ }^{\circ} \mathrm{C}$ under high vacuum conditions. The application of a galvanostatic step induces a polarization of the Pt particles forming galvanic cells. The number of equivalent $n_{\text {cell }}$ has been estimated as a function of the applied current from the variation of the oxygen evolution.

The use of isotopically labeled oxygen allows the discrimination of the faradaic process $\left({ }^{16} \mathrm{O}\right.$ from YSZ) from the non-faradaic process $\left({ }^{18} \mathrm{O}\right.$ from $\left.{ }^{18} \mathrm{O}_{2}\right)$. This allows for the first time to determine the $\Lambda$ and $\rho$ parameters in a bipolar system. Polarization of the particles clearly increases their catalytic efficiency.

\section{References}

[1] C.G. Vayenas, S. Bebelis, S. Ladas, Nature 343 (1990) 625.
[2] C.G. Vayenas, S. Bebelis, C. Pliangos, S. Brosda, D. Tsiplakides, Electrochemical Activation of Catalysis: Promotion, Electrochemical Promotion and MetalSupport Interactions, Kluwer Academic/Plenum Publishers, New York, 2001.

[3] C.G. Vayenas, S. Bebelis, Catal. Today 51 (1999) 58.

[4] M. Marwood, C.G. Vayenas, J. Catal. 168 (1997) 538.

[5] S. Wodiunig, F. Bokeloh, J. Nicole, Ch. Comninellis, Electrochem. Solid-State Lett. 2 (6) (1999) 281.

[6] C. Pliangos, C. Raptis, I. Bolzonella, Ch. Comninellis, C.G. Vayenas, Ionics 8 (2002) 372.

[7] S. Wodiunig, F. Bokeloh, Ch. Comninellis, Electrochim. Acta 46 (2000) 357.

[8] S. Balomenou, G. Pitselis, D. Polydoros, A. Giannikos, A. Vradis, A. Frenzel, C. Pliangosa, H. Pütter, C.G. Vayenasa, Solid State Ionics 136-137 (2000) 857.

[9] Ch. Comninellis, E. Plattner, P. Bolomey, J. Appl. Electrochem. 21 (1991) 415.

[10] A. Katsaounis, Z. Nikopoulou, X.E. Verykios, C.G. Vayenas, J. Catal. 226 (2004) 197.

[11] C. Falgairette, C. Xia, Y.D. Li, W. Harbich, C. Comninellis, J. Appl. Electrochem. 40 (2010) 1893.

[12] H. Jödicke, R. Schaub, A. Bhowmick, R. Monot, J. Buttet, W. Harbich, Rev. Sci. Instrum. 71 (2000) 2818.

[13] C. Falgairette, C. Xia, Y.D. Li, W. Harbich, G. Foti, C. Comninellis, J. Appl. Electrochem. 40 (2010) 1901. 